\title{
口蓋裂患者の口蓋帆挙筋の組織像と筋電図
}

\author{
酒巻 牧子1) $\cdot$ 安岡 義人1) ・吉見 富夫 ${ }^{2)}$ \\ 川島 理1) ・亀井 民雄 ${ }^{1)} \cdot$ 中里 洋一3)
}

\section{Histology and Electromyography of the Levator Veli Palatini Muscle in Patients with Cleft Palate}

\author{
Makiko Sakamaki, Yoshihito Yasuoka, Tomio Yoshimi, \\ Osamu Kawashima, Tamio Kamei and Yoichi Nakazato \\ (Gunma University)
}

In some patients with cleft palate (CP), velopharyngeal insufficiency persists after palatoplasty. In order to determine whether such insufficiency is due to the pathological changes of the levator veli palatini (LVP) muscle, we examined histologically the LVP muscles of 35 patients with CP and of six control patients with congenital microtia. Electromyographic records were obtained of the LVP muscles of 12 patients with CP after palatoplasty.

The muscle structures were well preserved in seven of 35 patients with CP. Among the other 28 patients, perimysial fibrosis was observed in 13, variations in fiber caliber in seven and internal nuclei in one, but these findings were also observed in the control group. The incidence of each finding was not significantly different between the two groups. Electromyography revealed the mean action potential during phonation of the sound "ah" to be $825 \mu \mathrm{V}$. Effective elevation of the soft palate was correlated with neither the histology nor the action potential of the LVP muscle.

Therefore velopharyngeal insufficiency persisting after palatoplasty is considered not to be due to pathological changes in the LVP muscle.

Key words: levator veli palatini muscle, cleft palate, histology, electromyography, velopharyngeal insufficiency

緒言

口蓋裂患者の口蓋帆挙筋は破裂部で分離され， 後方から前方へ異常走行して硬口蓋後端に付着 する1)2)， 口蓋形成術では pushback と筋の再配 列により挙筋索を形成し，軟口蓋の後上方への 挙上運動を回復することにより鼻咽腔閉鎖機能
の改善を図る314)。ところが術後も鼻咽腔閉鎖 機能の改善しない場合があり，その原因として 手術手技や術後の変化の他に口蓋帆挙筋の筋萎 縮の有無が論じられている. Surina ら5) は口蓋 裂11例の口蓋帆挙筋の筋電図に発声時活動電位 の低下と持続時間の短縮を認め, 組織学的にも

1) 群馬大学医学部耳鼻咽喉科学教室

2) 群馬大学医学部第一解剖学教室

3）群馬大学医学部第一病理学教室 
筋束の分布が疎で比較的少数の筋線維が幅広い 結合織により分けられていたと報告している。 木村 ${ }^{6}$ は術後に鼻咽腔閉鎖不全の残った軟口蓋 裂の一症例に拈いて, 組織学的には筋線維の消 失と線維性結合織の増生を特徵とする筋萎縮像 を認め, 筋電図では発声時活動電位の低下を認 めたと報告している。一方, 名倉ら7) は口蓋裂 患者 16 人の口蓋帆挙筋に中心核・線維の群集萎 縮や肥大などの neurogenic あるいは myogenic change は認められなかったと報告しており， 口蓋帆挙筋の筋萎縮の有無については未だ見解 の一致を見ていない，そこで我々は口蓋裂患者 の口蓋帆挙筋の組織検査と筋電図検査を行い, 術後の鼻咽腔閉鎖機能との関係を調べることに より， 口蓋形成術後に残る鼻咽腔閉鎖不全の原 因が口蓋帆挙筋の筋萎縮にあるか否かを検討し た。

\section{対象ならびに方法}

\section{1. 対 象}

口蓋帆挙笳の組織検査を行ったのは, 1982年 7 月から1989年 2 月までに群馬大学附属病院に 拈いて口蓋形成術を行った口蓋裂患者 35 人であ る. その裂の程度の内訳は唇・口蓋裂16例, 軟 - 硬口蓋裂 10 例, 軟口蓋裂 7 例, 粘膜下口蓋裂 2 例である. 口蓋形成術は pushback 法により 行い, その時期は 1 歳 3 力月から 2 歳 10 力月の 間である。ただし，初診が遅かった粘膜下口蓋 裂の 1 例には 12 歳 6 カ月で手術を行っている. 後に，35例中 2 例に咽頭弁手術を行っている.

一方, 先天性小耳症患者 6 人の健側口蓋帆挙 筋の組織を対照とした．先天性小耳症では患側 の軟口蓋麻痺を伴らことがあり, 以前口蓋帆挙 筋の組織学的検索を行ったことがある8)ので, これらの症例の組織を利用したものである．健 側軟口蓋には麻痺はなく，同時に行った筋電図 検査でも異常を認めていない、組織を採取した 年齢は 5 歳 0 力月から 13 歳 10 力月, 平均 6 歳 2 カ月である.

口蓋帆挙筋の筋電図検査を実施したのは上記 口蓋裂患者 35 人のうち 6 歳に達し検査に協力で
きた 12 人で, 術後 1 年 9 力月から 7 年 2 力月, 平均 5 年 2 カ月の時点で検査を行った。これら の症例の裂の程度の内訳は唇・蓋裂 8 例, 軟 - 硬口蓋裂 1 例, 軟口蓋裂 1 例, 粘膜下口蓋裂 2 例である。

\section{2 . 組織検査}

口蓋形成術の際, 破裂部硬口蓋後端に付着す る口蓋帆挙筋を剝離し; その断端中央部より組 織を採取した(図: 1-A)。一方, 小耳症症例で は耳介形成術の際に，健側 hamulus 基部々硬 口蓋正中線の中線上で硬口蓋後端より $5 \mathrm{~mm}$ 後 万の点に約 $1 \mathrm{~cm}$ の横切開を加光, 健側口蓋帆 挙筋組織を採取した(図 1-B). 尚, 組織採取 にあたり，その目的と患児に与兄る影響を両親 に説明し了解を得た。また採取による影響を小 さくするために，採取組織は $1 \sim 2 \mathrm{~mm}$ 長の小 片にとどめた.

組織は $10 \%$ 緩衝ホルマリンで固定し，パラフ ィンに包埋して薄切した. 切片はへマトキシリ ン・エオジン染色を施して光学顕微鏡にて観察 した。

\section{3 . 筋電図検査}

左右各々の口蓋帆挙筋に経口的に $6 \mathrm{~cm}$ 長の 同心針電極を刺入し, 安静呼吸時, 「ア」発声 時の活動電位を記録した.刺入部位は hamulus

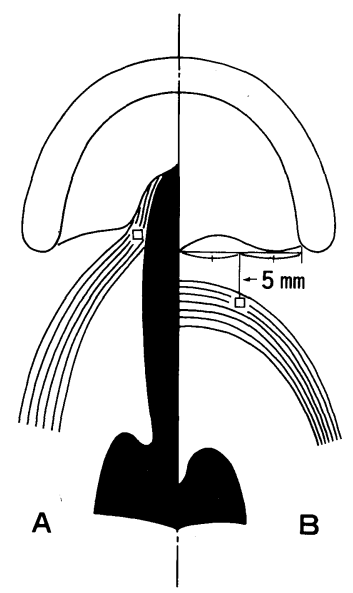

図1 口蓋帆挙筋組織の採取部位 A：口蓋裂 B：小耳症 
基部から内側約 $5 \mathrm{~mm}$, 硬口蓋後端加ら後方約 8 mmの点を目安にした。

4. 術後の鼻咽腔閉鎖機能

術後の軟口蓋挙上運動の良否をスコア化し， 母音「ア」発声時に口内視診により判定して軟 口蓋挙上の良い場合を 2 点，挙上のやや悪、場 合を 1 点，汪とんど動かない場合を０点とした。 筋電図検査を行った 12 人については, fiberscope で経鼻的にも鼻咽腔閉鎖の良否を観察した。

\section{結果}

\section{1 。組織所見}

筋組織の形態が良く保たれて拈り，fibrosis - 筋線維の口径の大小不同・中心核・群束性萎

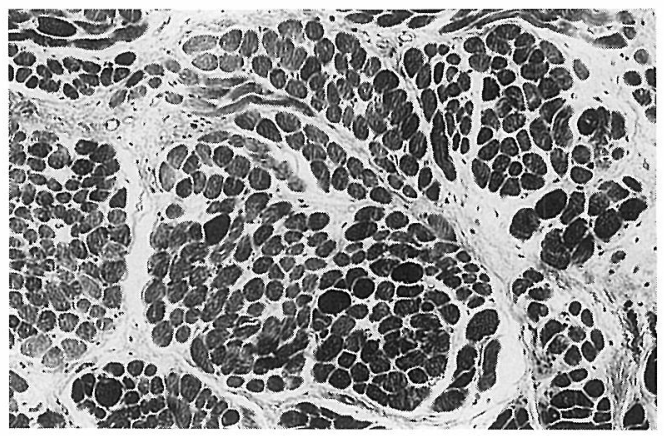

図 2 preserved type

等線維の口径は注淩均一で，個々の線維の形態も 良く保たれている. endomysium, perimysium に 線維化や脂肪織浸潤も認められない。

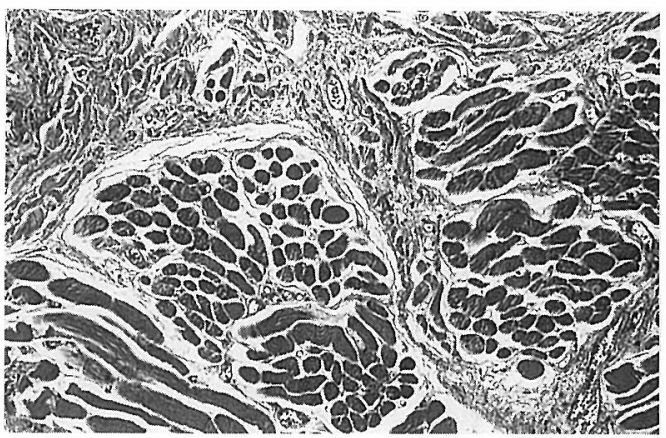

図 3 perimysial fibrosis

筋線維束を取り围むような線維性結合織の増生を 認める。
縮などを認めないもの（図 2 )を preserved type, これらの所見のいずれかを認めるものをnonpreserved type と呼ぶことにする. preserved type は，口蓋裂35例中 7 例 (20\%)，対照 6 例

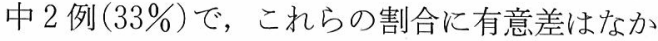
った $\left(0.1<\mathrm{p}<0.5, \chi^{2}\right.$ 検定による. 以下同様). non-preserved type に認めた組織所見は， perimysial fibrosis（図 3 ) ・筋線維の口径の大 小不同(図 4)・中心核の出現(図 5 )である。筋 線維束を取り囲むような広範な線維性結合織の 増生を認め，筋束の分布が疎であるものを perimysial fibrosis $(H)$, perimysium $の$ 線維性 結合織がやや増加しているものを perimysial

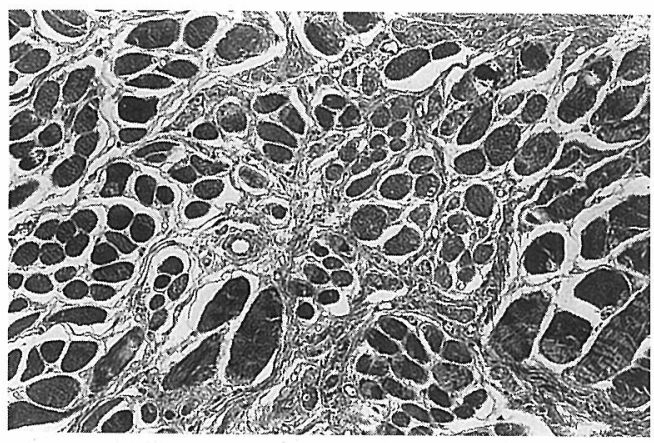

図 4 筋線維の口径の大小不同

筋線維の口径に大小不同が目立つ. endomysium には線維化も認められる。

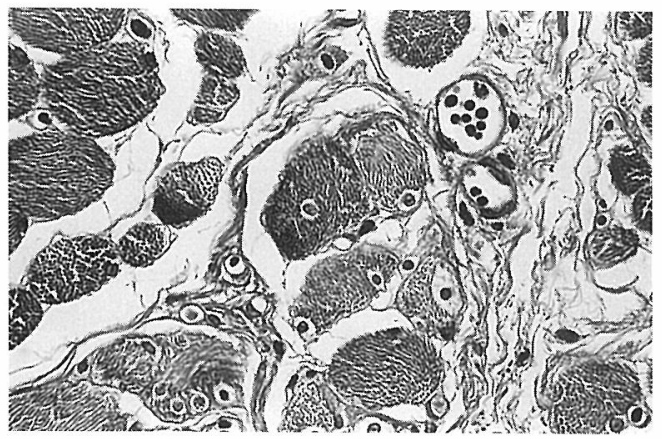

図 5 中心核

一部の筋線維では核が細胞質の中心に移動し，中 心核の所見を示している。 
fibrosis $(+)$ とすると, 口蓋裂では $(H)$ が 8 例 $(23 \%) ，(+)$ が 5 例(14\%)，対照では(H)と (+)が各々 1 例 (各17\%)であり，これらの割合 には有意差はなかった $(0.5<\mathrm{p})$. 筋線維の口径 の大小不同と中心核の出現は, 各々その所見の 明らかなものを $(+)$, ごく軽度で病的と解すべ きかどらか疑わしいものを(士)とした。筋線維 の口径の大小不同は, 口蓋裂では $(+)$ が 7 例 (20\%)，（土)が10例(29\%)，対照では(+)はな

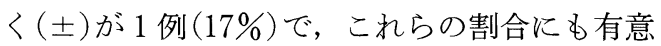
差はなかった $(0.1<\mathrm{p}<0.5)$. 中心核の出現は， 口蓋裂では $(+)$ が 1 例 $(3 \%) ，( \pm)$ が 6 例 $(17$ $\%)$ ，対照では $(+)$ と $( \pm)$ が各々 1 例 (各 $17 \%)$ で, これらの割合にも, やはり有意差はなかっ
た $(0.1<\mathrm{p}<0.5)$.

2 . 筋電図

発声時活動電位は $100 \sim 1200 \mu \mathrm{V}$, 平均 825 $\mu \mathrm{V}$ で， 1 例が $100 \mu \mathrm{V}$ の低電位であった他は $500 \mu \mathrm{V}$ 以上であった。 また tonic discharge は 認めなかった。両側口唇・口蓋裂，片側口唇・ 口蓋裂, 軟・硬口蓋裂, 軟口蓋裂の各 1 例の筋 電図を図 6 亿示す。

3 . 術後の鼻咽腔閉鎖機能

術後 1 年の軟口蓋挙上スコアは，35例中25例 (71\%) が 2 点， 7 例 $(20 \%)$ が 1 点， 3 例 ( $9 \%$ ) が 0 点であった．術後軟口蓋挙上スコアが 2 点 になるまでに要する期間は 1 週間から 1 年と, 症例によりかなり差があった。

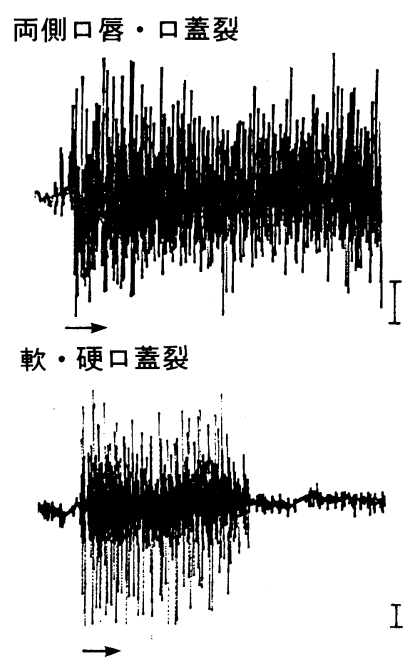

片側口唇・ロ蓋裂

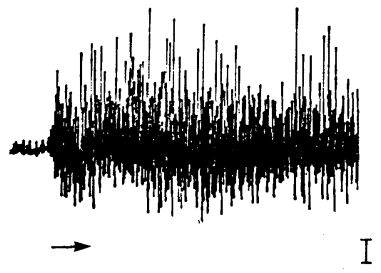

軟口蓋裂

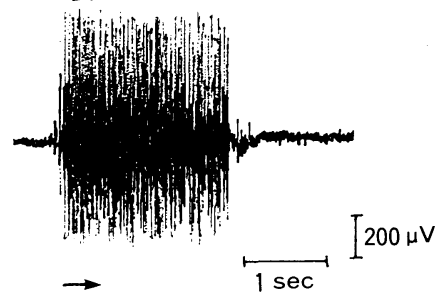

$\rightarrow$ は発声「ア」

図 6 口蓋帆挙筋の筋電図例

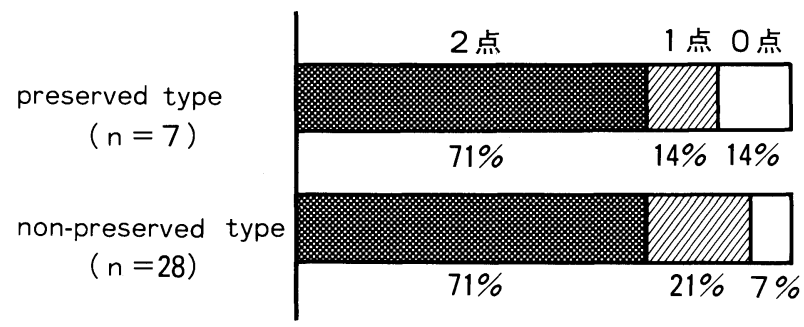

図 7 組織所見と軟口蓋挙上スコア 
4. 組織所見, 筋電図, 術後の鼻咽腔閉鎖機 能の関連性

1 ) 組織所見と発声時活動電位

発声時活動電位が正常であった11例中, 組織 が preserved typeであったのは 2 例のみで，そ の他では perimysial fibrosis(H)が 3 例, (+) が 2 例に, 筋線維の口径の大小不同 $(+)$ が 4 例 に, 中心核の出現 $(+)$ が 1 例に認められた。発 声時活動電位が $100 \mu \mathrm{V}$ であった 1 例では，筋 線維口径の大小不同 $( \pm)$ の他は組織に著変を認 めなかった。

2 ) 組織所見と軟口蓋挙上スュア (図 7)

術後 1 年の軟口蓋挙上スコアは, 組織が preserved type であった 7 例中， 5 例(71\%)が 2 点, 1 例 $(14 \%)$ ずつが 1 点と 0 点であり, nonpreserved type の28例中, 20例(71\%)が 2 点， 6 例 $(21 \%)$ が 1 点, 2 例 $(7 \%)$ が 0 点であった. 両者の間に有意差はなかった $(\mathrm{p}>0.5)$. perimysial fibrosis - 筋線維口径の大小不同 - 中心 核の出現などの有無と術後 1 年の軟口蓋挙上ス コアとの間にも特別な関係は認められなかった.

3 ) 発声時活動電位と軟口蓋挙上スュア

発声時活動電位が正常であった 11 例中 9 例 (82\%)では，軟口蓋挙上スュア(筋電図測定時)

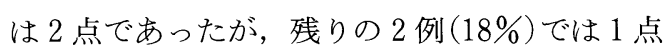
であった．発声時活動電位が $100 \mu \mathrm{V}$ であった 1 例では, 軟口蓋挙上スュアは 2 点であった。

\section{考察}

一般にヒトの骨格筋では fibrosis は筋萎縮を， 筋線維の口径の大小不同・中心核の出現は特に 筋原性筋萎縮を示唆する組織所見である ${ }^{9}$. し かし口蓋帆挙筋に関してはこれまで正常な組織 像についての報告がなく, 従ってこれらの所見 が口蓋帆挙筋においても直ちに病的所見と言え るかどらかは疑問である。この点例えば，ヒト の外眼筋では中心核の出現は正常でも認められ ることが知られている10). 従って, 口蓋裂患者 の口蓋帆挙筋の組織学的異常について論じるた めには，正常な口蓋帆挙筋の組織所見を知る必 要があり, 今回我々は, 先天性小耳症患者の健
側口蓋帆挙筋を対照とした。これらに抌いて健 側の軟口蓋挙上は良好で, 筋電図でも異常を認 めなかった. 年齢構成に $4 \sim 5$ 歳の差があるが, 対照として適切と考えた。

結論としては, perimysial fibrosis・筋線維 の口径の大小不同・中心核の出現などの組織所 見を認めた症例の割合には, 口蓋裂と対照との 間に統計学的有意差を認めなかった. 従って, これらの所見は口蓋帆挙筋においては一般の骨 格筋の場合とは異なり, 病的な所見とはみなし がたいと考えた．この点，口蓋裂患者の口蓋帆 挙筋に萎縮を認めるとする山口ら ${ }^{11)}$, 木村6), Surina ら5) とは見解を異にする。

筋電図所見に扔いても発声時活動電位が低い のは 1 例のみであった.この 1 例も軟口蓋の挙 上は良く，軟口蓋に幅広い洀痕を認めたことか ら術後性瘢痕による低電位と考えた。

術後の軟口蓋挙上スコアと, perimysial fibrosis - 筋線維の口径の大小不同・中心核の出 現などの組織所見の有無, 発声時活動電位の良 否の間には相関を認めなかった。 このことから も，これらの所見は筋萎縮を示唆するものでは ないと考えた。

発声時活動電位が正常であるにもかかわらず 軟口蓋挙上スコア (筋電図測定時)が 1 点であっ た2 例は，咽頭弁手術を行なった症例で，形成 した挙筋索の周囲の術後性瘢痕や筋の量的不足 が推測された. 軟口蓋挙上スコアが 2 点であっ たにもかかわらず発声時活動電位が低かった 1 例は, 既述の如く軟口蓋の術後性瘢痕が強かっ た症例であり, 口蓋帆挙筋の筋萎縮による低電 位とは考光難い。

口蓋形成術後に残る鼻咽腔閉鎖不全は, 口蓋 帆挙筋の筋萎縮によるものではなく, むしろ, 手術手技や術後の変化, また口蓋帆挙筋の量的 不足によるものとも推測される.

\section{結 論}

1. 口蓋帆挙筋において perimysial fibrosis ・筋線維の口径の大小不同・中心核の出現など の組織所見は, 一般の骨格筋の場合と異なり必 
ずしも病的でなく、また筋萎縮も示唆しない:

2. 筋電図検查でも，この筋に打いて術後に 発声時活動電位の低下はほとんど認めない.

3. 口蓋帆挙筋の組織所見, 発声時活動電位 の良否, 和よび術後の軟口蓋挙上スコアの間に 特別な相関を認めない。

4: 以上より, 口蓋裂患者の口蓋帆挙筋には 筋萎縮はなく、口蓋形成術後に残る鼻咽腔閉鎖 不全の原因をここに求めることはできない．

本論文の要旨は，第52回耳鼻咽喉科臨床学会 (久留 米)に扎いてロ演した。

\section{参考文献}

1) Kriens $O$ : Anatomy of the velopharyngeal area in cleft palate. Clin Plast Surg $2: 261 \sim$ 283, 1975.

2) 内藤 泰, 田坂康之, 本庄 嚴, 他：口蓋裂の MRI (核磁気共鳴画像)。耳鼻臨床 $80: 435$ 440, 1987.

3）本庄 㦑：機能面よりみた口蓋裂手術.耳鼻臨 床 $69: 35 \sim 38,1976$.

4) 本庄 樷, 原田寿利, 岡崎伸博, 他：口蓋裂手 術における挙筋索形成の意義一電気刺激によ る検討一. 耳鼻臨床 $73: 33 \sim 36,1980$.
5) Surina I and Jagr J : Action potentials of levator and tensor muscles in patients with cleft palate. Acta Chir Plast 11:21 30, 1969.

6）木村 照: 軟口蓋筇萎縮を伴った口蓋裂症例. 耳鼻臨床 $70: 1567 \sim 1570,1977$.

7）名倉英明, 谷 政澄, 富塚清二, 他 : 口蓋裂患

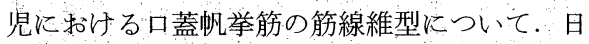
口外誌 $30: 2156,1984$.

8）吉見富夫, 安岡義人, 今村純子 : 先天性小耳症 飞合併する軟口蓋麻疩. 日形会誌 $6: 743 \sim 744$, 1986.

9) Harriman DGF : Diseases of muscle. Greenfield's Neuropathology (ed by Adams JH, et al). pp 1026 1096, Arnold, London, 1984.

10）岡本俊子：ヒトの外眼筋の形態学的研究. 臨床 神経学 $22: 393 \sim 401,1982$.

11）山口 忍, 工田昌也, 平良達三, 他 : 七ト口蓋 帆挙筋の形態学的, 組織化学的検討. 耳鼻臨床 $82: 1779 \sim 1784,1989$.

$$
\left(\begin{array}{l}
\text { 原稿受付: 平成 } 3 \text { 年 } 1 \text { 月 } 7 \text { 日 } \\
\text { 原稿採択 : 平成 } 3 \text { 年 } 2 \text { 月 } 27 \text { 日 } \\
\text { 別刷請求先 : 酒巻牧子 } \\
\text { † } 371 \text { 前橋市昭和町 } 3-39-15 \\
\text { 群馬大学医学部耳鼻咽喉科学教室 }
\end{array}\right)
$$

